\title{
Comparison of the endoparasite fauna of Hoplias malabaricus and Hoplerythrinus unitaeniatus (Erythrinidae), sympatric hosts in the eastern Amazon region (Brazil)
}

\author{
M. S. B. OLIVEIRA ${ }^{1,5 *}$, L. LIMA CORRÊA2 ${ }^{2}$, L. PRESTES ${ }^{3}$, L. R. NEVES ${ }^{4,5}$, A. R. P. BRASILIENSE ${ }^{1,5}$, D. O. FERREIRA ${ }^{5}$, \\ M. TAVARES-DIAS ${ }^{1,4,5}$
}

\begin{abstract}
1Postgraduate Program in Tropical Biodiversity - PPGBIO, Universidade Federal do Amapá - UNIFAP, Rod. Juscelino Kubitschek, KM-02, CEP 68.903-419, Jardim Marco Zero, Macapá, Amapá, Brazil, *E-mail: marcosidney2012@hotmail.com; '2Universidade Federal do Oeste do Pará - UFOPA, Av. Mendonça Furtado, n 2946, Fátima, CEP 68040-470, Instituto de Ciências e Tecnologia das Águas - ICTA, Santarém, Pará, Brazil, E-mail: lincorre@gmail.com; ${ }^{3}$ Postgraduate Program in Aquatic Ecology and Fisheries PPGEAP, Universidade Federal Rural da Amazônia - UFRA. Av. Presidente Tancredo Neves, nº 2501, Terra Firme, CEP 66077-830, Belém, Pará, Brazil and Universidade do Estado do Amapá - UEAP, Av. Presidente Vargas n 100, CEP 66077-830, Central, Macapá, Amapá, Brazil, E-mail: Iuliprestes@gmail.com; ${ }^{4}$ Postgraduate Program in the Biodiversity and Biotechnology of the Legal Amazon - PPGBIONORTE - AP. Universidade Federal do Amapá - UNIFAP, Rod. Juscelino Kubitschek, KM-02, CEP 68.903-419, Jardim Marco Zero, Macapá, Amapá, Brazil. E-mail: liahrigor@hotmail.com; ${ }^{5}$ Embrapa Amapá, Rodovia Juscelino Kubitschek, Km 5, $n^{0} 2600$, Universidade, CEP 68903-419, Macapá, Amapá, Brazil, E-mail: driellyferreira2015@outlook.com; marcos.tavares@embrapa.br
\end{abstract}

Article info

Received September 19, 2017 Accepted January 16, 2018

\begin{abstract}
Summary
Hoplias malabaricus and Hoplerythrinus unitaeniatus are Erythrinidae family widely distributed in the Amazon River system of great value to both commercial and subsistence fishing for riverine populations. As such, the objective of the present study was to investigate the endoparasite communities of $\mathrm{H}$. malabaricus and $\mathrm{H}$. unitaeniatus of a tributary of the Amazon River in the north of Brazil. The endoparasite communities of $H$. unitaeniatus and $H$. malabaricus were taxonomically similar $(85 \%)$ and consisted of Clinostomum marginatum, Contracaecum sp., Guyanema seriei seriei, Procamallanus (Spirocamallanus) inopinatus, Pseudoproleptus sp. and Gorytocephalus spectabilis, although the dominant endoparasite was $C$. marginatum, which was the most prevalent and abundant. All the specimens of both $H$. malabaricus and $H$. unitaeniatus were parasitized, with a total of 1237 helminths collected in the former host and 1151 helminths collected in the latter. Hoplerythrinus unitaeniatus possessed greater parasite species richness. Both hosts had an aggregate dispersion of parasites, and the abundance of $C$. marginatum, Contracaecum sp. and $G$. spectabilis correlated positively with the weight and length of the hosts. The condition factor was not affected by parasitism, but the abundance of $\mathrm{C}$. marginatum and Contracaecum sp. increased when the condition factor of the hosts decreased. This is the first report of G. seriei seriei for $H$. malabaricus and Pseudoproleptus sp. for H. unitaeniatus.

Keywords: Amazon; Vila Nova River; Erythrinidae; helminth parasites
\end{abstract}

\section{Introduction}

The state of Amapá has 34 hydrographic basins, including the Vila Nova River basin, which is one of the largest in the state (Zee, 1997; Silva et al., 2006), and covers the municipalities of Santana and Mazagão, flowing into the Amazon River near Santana. The Vila Nova is a white-water river with a pH of 5-7 (Cunha, 2003). Besides being important for navigation and water supply (Silva et al., 2006), it is home to several species of fish, including the Erythrinidae family (including Hoplias malabaricus Bloch, 1794 and Hop-

\footnotetext{
$\overline{* \text { - corresponding author }}$
} 
lerythrinus unitaeniatus Spix \& Agassiz, 1829), as it possesses an extensive flood plain area. Amazon floodplain lakes are complex environments, whose spatial heterogeneity spans such distinct habitats as flooded forests, macrophyte meadows and open water. These habitats provide areas which are used by several fish species for shelter, feeding, growth and reproduction during different phases of their life cycles. The seasonal component (rainy and dry seasons) adds additional complexity to the floodplain habitat by altering the availability of these habitats to fish over the course of the year (Siqueira-Souza et al., 2017).

Hoplias malabaricus and $H$. unitaeniatus are common Erythrinidae from the Amazon River system, and are important for commercial and subsistence fishing (Santos et al., 2006; Soares et al., 2011; Gonçalves et al., 2016). Both fish inhabit rivers, lakes and flooded forests (Mattox et al., 2006). The young of $H$. malabaricus and $H$. unitaeniatus feed on plankton such as microcrustaceans and insects, while adults feed mainly on fish and shrimp. They can tolerate low concentrations of dissolved oxygen in the water and take care of their offspring (Santos et al., 2006; Soares et al., 2011). The occurrence of $H$. malabaricus and $H$. unitaeniatus can be observed in various environments, and their carnivorous diet and elevated position in the food chain, makes them good host models in parasitic ecology (Alcântara \& Tavares-Dias, 2015; Gonçalves et al., 2016).

In the Amazon region of South America, the parasite fauna of $H$. malabaricus and $H$. unitaeniatus consists of 17 species, of which seven are endoparasites of $H$. unitaeniatus and ten are endoparasites of $H$. malabaricus (Alcântara \& Tavares-Dias, 2015; Gonçalves et al., 2016). The rainy and dry seasons create variations in the availability of food in Amazon habitats, leading to fluctuations in the infracommunities of the parasites of the two hosts (Gonçalves et al., 2016). However, the size of these two hosts has no relation to the abundance of parasites (Alcântara \& Tavares-Dias, 2015; Gonçalves et al., 2016).

The relationship between parasites and hosts can be regulated by the host mortality induced by parasites. Abundant hosts generally tend to harbor richer parasite fauna, but if the host species are less numerous, their parasite fauna may become less rich (Morozińska-Gogol, 2015). As $H$. malabaricus and $H$. unitaeniatus are abundant hosts in the floodplain area of the Amazon River system and have a similar life history, will they present a similar community of endoparasites? Populations of hosts with a similar life history that live in the same geographical area and are exposed to the same infection stages may present a qualitatively and quantitatively similar community of endoparasites when they ingest similar quantities and types of prey. In this manner, overlapping in the same area of occurrence may have an important effect on endoparasite communities in phylogenetically related hosts (Alarcos \& Timi, 2012; Alcântara \& Tavares-Dias, 2015; Hoshino et al., 2016; Oliveira et al., 2016).

Parasites can regulate the growth of host fish populations, reducing fertility and affecting the swimming, feeding and behavior of these animals (Corrêa et al., 2014; Machado et al., 2013; Hoshino et al., 2016). Knowledge of the parasites of natural populations can be important for decision-making regarding the monitoring of fish stocks, as they generate information about the physical conditions of fish (Corrêa et al., 2013). As such, the objective of this study was to comparate the endoparasites fauna of $H$. malabaricus and $H$. unitaeniatus in a floodplain area of the basin of the Vila Nova River, a tributary of the Amazon River, Northern Brazil.

\section{Materials and Methods}

\section{Fish and collection location}

In October 2015 (dry season), 30 specimens of $H$. unitaeniatus and 30 specimens of $H$. malabaricus were captured in the floodplain region of the Vila Nova River in the municipality of Mazagão, a tributary of the Amazon River, in the state of Amapá, Brazil (Fig. 1), for parasitological analysis. Gill nets were used to capture the fish ( 30 and $35 \mathrm{~mm}$ between knots). The fish were transported in boxes with ice to the Laboratory of Aquaculture and Fishery from Embrapa Amapá.

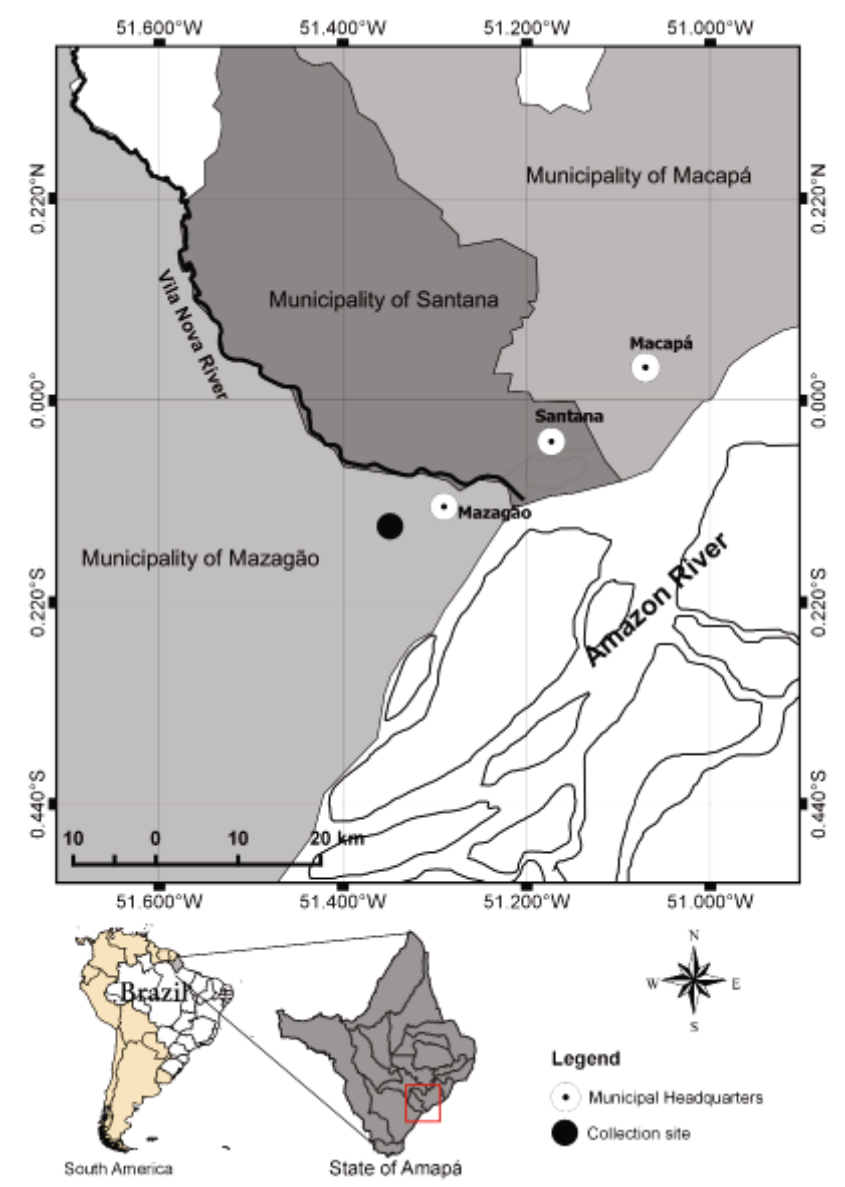

Fig. 1. Geographic location of collection site of Hoplias malabaricus and Hoplerythrinus unitaeniatus in the Vila Nova River basin, eastern Amazon region (Brazil). 
The Vila Nova River and its floodplain areas are strongly influenced by tides through the Amazon River, and in the rainy season fish enter the floodplain areas in search of food. In dry seasons, however, these areas are reduced and have a low dissolved oxygen level (Silva et al., 2006).

\section{Collection, fixation and identification procedures of parasites}

After collection, the fish were euthanized by the spinal cord transection method and weighed $(\mathrm{g})$ and measured for standard length (cm). The fish were then necropsied for parasitological analysis. This work was carried out in accordance with the principles adopted by the Colégio Brasileiro de Experimento Animal (Brazilian College of Animal Experimentation -Cobea) with the authorization from Ethics Committee in the Use of Animals of Embrapa Amapá (\#:004 - CEUA/CPAFAP).

After necropsy, the gastrointestinal tract and viscera were analyzed using a stereomicroscope and a light microscope to collect endoparasites. The methodology used to fix, preserve, quantify and stain the parasites for identification was that recommended by Eiras et al. (2006). The parasites were identified in accordance with Petter (1975), Moravec (1998), Moravec \& Santos (2009), Vicente \& Pinto (1999), Thatcher (2006) and Caffara et al. (2011). The ecological terms proposed by Rohde et al. (1995) and Bush et al. (1997) were used.

\section{Data analysis}

The Brillouin diversity index $(H B)$, uniformity $(E)$, Berger-Parker dominance index $(d)$ and species richness of the parasites (Magurran, 2004) was calculated to evaluate the endoparasite component community using the Diversity software package (Pisces Conservation Ltd, UK). The index of dispersion (ID) and discrepancy index (D) were calculated using Quantitative Parasitology 3.0 software to detect the distribution pattern of the parasite infracommunities (Rózsa et al., 2000) for species with a prevalence of $>10 \%$. The significance of the (ID), for each infracommunity, was tested using the $d$-statistics test (Ludwig \& Reynolds, 1988). The Jaccard index $(\mathrm{J})$ and Bray-Curtis index (B) were used to measure similarity in parasite abundance between $H$. unitaeniatus and $H$. malabaricus. These take into account the differences in abundance between the shared parasite species (Ludwig \& Reynolds, 1988; Magurran, 2004). These similarity indices were calculated using the Past software (Hammer et al., 2001). Principal component analysis (PCA) was carried out to compare the ways in which body size and diversity influenced the parasite communities of $H$. unitaeniatus and $H$. malabaricus. This analysis was performed using the Past software (Hammer et al., 2001).

The total weight $(\mathrm{g})$ and standard length $(\mathrm{cm})$ of the fish were used to calculate the relative condition factor $(\mathrm{Kn})$ of the hosts and the weight-length ratio using the equation $W=a \cdot L^{b}$, where $W$ is the total weight $(\mathrm{g})$ and $\mathrm{L}$ is the standard length $(\mathrm{cm})$, $a$ and $b$ are con-

Table 1. Helminth parasites of two Erythrinidae species from the Vila Nova River basin, eastern Amazon region (Brazil).

P: Prevalence, MI: Mean intensity, MA: Mean abundance, TNP: Total number of parasites, SI: Site of infection, FD: Frequency of dominance.

\begin{tabular}{|c|c|c|c|c|c|c|c|c|c|c|c|c|}
\hline \multirow{2}{*}{$\begin{array}{l}\text { Fish species } \\
\text { Parasites }\end{array}$} & \multicolumn{6}{|c|}{ Hoplerythrinus unitaeniatus $(\mathrm{N}=30$ ) } & \multicolumn{6}{|c|}{ Hoplias malabaricus $(\mathrm{N}=30)$} \\
\hline & $P(\%)$ & MI & MA & TNP & FD (\%) & SI & $\mathrm{P}(\%)$ & MI & MA & TNP & FD (\%) & SI \\
\hline Clinostomum marginatum (larvae) & 76.7 & 29.6 & 21.7 & 651 & 0.566 & Mesentery & 83.3 & 25.8 & 21.5 & 645 & 0.521 & Mesentery \\
\hline Clinostomum marginatum (larvae) & - & - & - & - & - & - & 3.3 & 2.0 & 0.07 & 2 & 0.002 & Intestine \\
\hline Clinostomum marginatum (larvae) & 6.7 & 1.5 & 0.10 & 3 & 0.002 & Musculature & - & - & - & - & - & - \\
\hline Pseudoproleptus sp. (larvae) & 33.3 & 4.9 & 1.63 & 49 & 0.042 & Intestine & 96.7 & 12.9 & 12.9 & 388 & 0.314 & Mesentery \\
\hline Pseudoproleptus sp. (larvae) & 26.7 & 6.8 & 1.80 & 54 & 0.046 & Liver & 13.3 & 4.0 & 0.5 & 16 & 0.013 & Intestine \\
\hline Pseudoproleptus sp. (larvae) & 13.3 & 1.8 & 0.23 & 7 & 0.006 & Caecum & - & - & - & - & - & - \\
\hline Pseudoproleptus sp. (larvae) & 66.7 & 5.3 & 3.50 & 105 & 0.090 & Mesentery & - & - & - & - & - & - \\
\hline Contracaecum sp. (larvae) & 83.3 & 3.4 & 2.87 & 86 & 0.074 & Mesentery & 90.0 & 5.5 & 4.8 & 143 & 0.116 & Mesentery \\
\hline Contracaecum sp. (larvae) & 10.0 & 3.0 & 0.10 & 3 & 0.002 & Cecum & 3.3 & 1.0 & 0.03 & 1 & 0.001 & Intestine \\
\hline Contracaecum sp. (larvae) & 10.0 & 1.0 & 0.10 & 3 & 0.002 & Liver & - & - & - & - & - & - \\
\hline Contracaecum sp. (larvae) & 3.3 & 1.0 & 0.03 & 1 & 0.0009 & Intestine & - & - & - & - & - & - \\
\hline Procamallanus (S.) inopinatus & 26.7 & 1.4 & 0.37 & 11 & 0.009 & Caecum & - & - & - & - & - & - \\
\hline Procamallanus (S.) inopinatus & 63.3 & 3.8 & 2.43 & 73 & 0.063 & Intestine & - & - & - & - & - & - \\
\hline Guyanema seriei seriei & 3.3 & 2.0 & 0.07 & 2 & 0.001 & Mesentery & - & - & - & - & - & - \\
\hline Gorytocephalus spectabilis & 60.0 & 3.5 & 2.10 & 63 & 0.054 & Intestine & 23.3 & 8.4 & 1.4 & 35 & 0.028 & Mesentery \\
\hline Gorytocephalus spectabilis & 3.3 & 4.0 & 0.13 & 4 & 0.003 & Liver & & & & & & \\
\hline Gorytocephalus spectabilis & 30.0 & 3.6 & 1.07 & 32 & 0.027 & Caecum & - & - & - & - & - & - \\
\hline Gorytocephalus spectabilis & 6.67 & 2.0 & 0.13 & 4 & 0.003 & Mesentery & - & - & - & - & - & - \\
\hline
\end{tabular}


Table 2. Index od dispersion (ID), d-statistic, and discrepancy index (D) for the infracommunities of parasitic helminths of two species of Erythrinidae from the Vila Nova River basin, eastern Amazon region (Brazil).

\begin{tabular}{lcccccc}
\hline Hosts fish & \multicolumn{3}{c}{ Hoplias malabaricus $\mathbf{( N = 3 0 )}$} & \multicolumn{3}{c}{ Hoplerythrinus unitaeniatus $(\mathbf{N}=\mathbf{3 0}$ ) } \\
\hline Parasites & ID & $d$ & D & ID & $d$ & D \\
\hline Gorytocephalus spectabilis (intestine) & 2.286 & 3.965 & 0.720 & 2.455 & 4.383 & 0597 \\
Pseudoproleptus sp. (intestine) & 1.975 & 3.153 & 0.871 & 2.063 & 3.389 & 0.730 \\
Pseudoproleptus sp. (liver) & - & - & - & 2.138 & 3.676 & 0.771 \\
Pseudoproleptus sp. (caecum) & - & - & - & 1.680 & 2.322 & 0.853 \\
Pseudoproleptus sp. (mesentery) & 2.236 & 3.849 & 0.323 & 2.811 & 5.219 & 0.507 \\
Procamallanus (S.) inopinatus (intestine) & - & - & - & 2.072 & 3.413 & 0.551 \\
Procamallanus (S.) inopinatus (caecum) & - & - & - & 1.219 & 0.859 & 0.754 \\
Clinostomum marginatum (mesentery) & 4.339 & 8.314 & 0.435 & 12.097 & 18.939 & 0.735 \\
Contracaecum sp. (mesentery) & 2.462 & 4.400 & 0.417 & 2.325 & 4.063 & 0.471 \\
Gorytocephalus spectabilis (cecum) & - & - & - & 2.670 & 4.701 & 0.767 \\
\hline
\end{tabular}

stants, estimated by the linear regression of the transformed equation: $W=\log a+b x \log C p$. (Le-Cren, 1951). The t-test was used to compare the $\mathrm{Kn}$ of hosts with the standard value $(\mathrm{Kn}=1.00)$. The Spearman coefficient ( $r s$ ) was used to determine the possible correlations between parasite abundance and host length, body weight and $\mathrm{Kn}$, as well as to correlate host length with species richness and $H B$. The Mann-Whitney $(U)$ test was used to compare the mean intensity, mean abundance, species richness, $H B$, $E$ and Berger-Parker dominance of both host species (Zar, 2010).

\section{Ethical Approval and/or Informed Consent}

This work was carried out in accordance with the principles adopt- ed by the Brazilian College of Animal Experimentation (Cobea) with the authorization from Ethics Committee in the Use of Animals of Embrapa Amapá (\#:004 - CEUA/CPAFAP).

\section{Results}

Thirty specimens of $H$. unitaeniatus measuring $\bar{x}=21.5 \pm 2.0 \mathrm{~cm}$ and $\bar{x}=245.3 \pm 65.6 \mathrm{~g}$, and 30 specimens of $H$. malabaricus with $\bar{x}$ $=24.9 \pm 7.7 \mathrm{~cm}$ and $\bar{x}=242.3 \pm 75.0 \mathrm{~g}$ were analyzed.

Of the specimens of $H$. unitaeniatus and $H$. malabaricus examined, $100 \%$ were parasitized by one or more species of helminth. It was observed that there was similar dominance of the digenean Clinostomum marginatum Rudolphi, 1819, in $H$. malabaricus and

Hoplias malabaricus
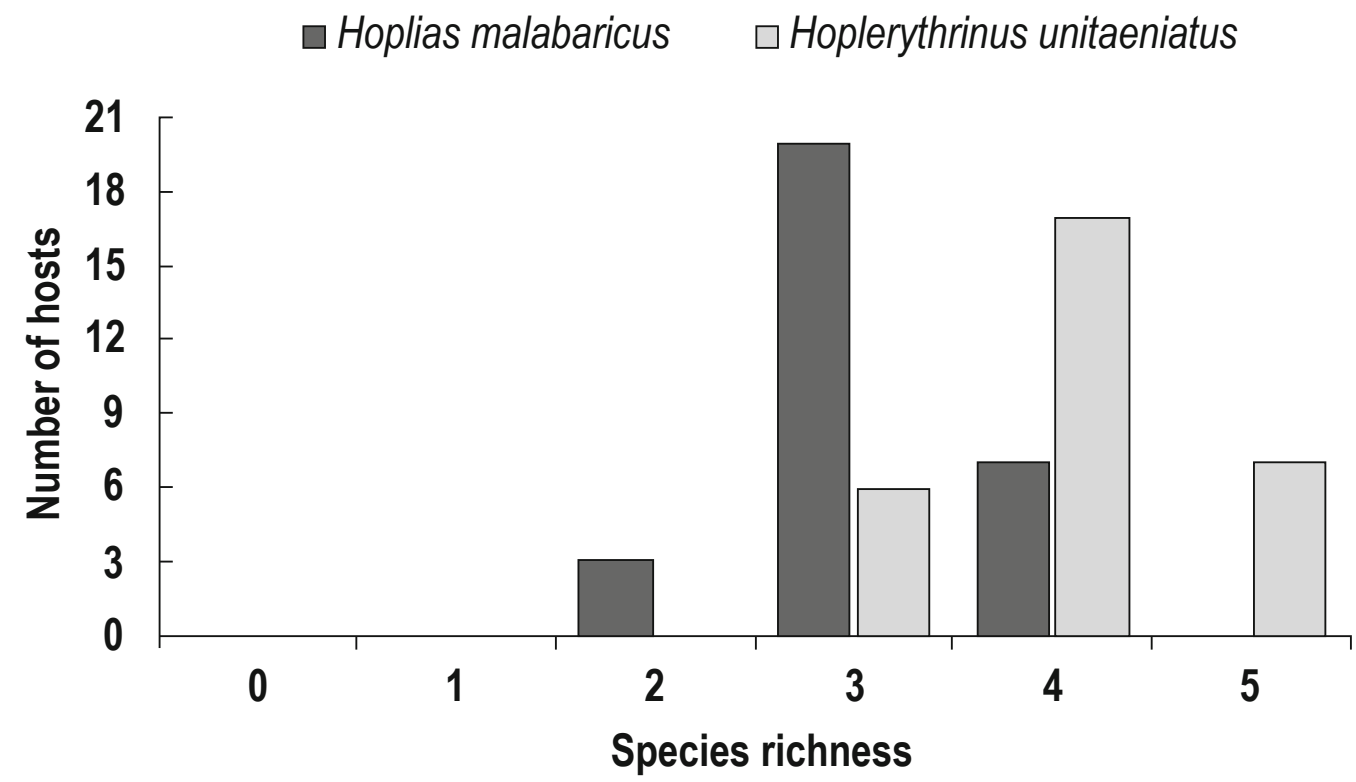

Fig. 2. Species richness of parasitic helminths of parasite helminths of two species of Erythrinidae from the Vila Nova River basin, eastern Amazon region (Brazil). 
Table 3. Diversity descriptors for infracommunities of parasitic helminths of two species of Erythrinidae from the Vila Nova River basin, eastern Amazon region (Brazil). $U=$ Mann-Whitney.

\begin{tabular}{lcccc}
\hline Mean indices of diversity & Hoplias malabaricus & Hoplerythrinus unitaeniatus & $U$ & $\boldsymbol{p}$ \\
\hline Species richness of parasites & $3.1 \pm 0.6(2-4)$ & $4.0 \pm 0.6(3-5)$ & 161.5 & 0.0001 \\
Brillouin $(H B)$ & $0.72 \pm 0.19(0.24-1.0)$ & $0.86 \pm 0.19(0.54-1.23)$ & 277.0 & 0.0053 \\
Evenness $(E)$ & $0.60 \pm 0.15(0.25-0.83)$ & $0.57 \pm 0.12(0.32-0.77)$ & 378.0 & 0.1436 \\
Dominance of Berger-Parker $(d)$ & $0.64 \pm 0.13(0.37-0.89)$ & $0.57 \pm 0.15(0.28-0.85)$ & 365.5 & 0.0467 \\
\hline
\end{tabular}

H. unitaeniatus, followed by Contracaecum sp. for both hosts. A total of 1151 helminths were collected in $H$. unitaeniatus and 1237 in $H$. malabaricus, making a total of 2,388 helminths. These parasites were distributed among the following taxa: Clinostomum marginatum (Trematoda), Guyanema seriei seriei Petter, 1975, Procamallanus (Spirocamallanus) inopinatus Travassos, Artigas \& Pereira, 1928, Pseudoproleptus Khera, 1955, Contracaecum Railliet \& Henry, 1912 (Nematoda) and Gorytocephalus spectabilis Machado, 1959 (Acanthocephala) (Table 1). These parasites presented aggregated dispersion, except $P$. (S.) inopinatus in the pyloric cecum of $H$. unitaeniatus that exhibited a random dispersion (Table 2).

Berger-Parker diversity index and evenness were similar for both fish species, but the Brillouin index $(H B)$ and species richness of the parasites were higher for $H$. unitaeniatus (Table 3 ), and there was no difference between the abundance $(U=430.5, p=0.309)$ and parasitic intensity $(U=430.5, p=0.309)$ in the two fish species. In $H$. malabaricus there was a predominance of individuals harboring three species of helminths, whereas in $H$. unitaeniatus the predominance was four species of helminths (Fig. 2).
The $H$. unitaeniatus and $H$. malabaricus populations exhibited low parasite community similarity, as described by the Jaccard index $(\mathrm{J}=0.66)$ and the Bray-Curtis index $(B=0.15)$. Multivariate analysis based on the parasite communities of $H$. unitaeniatus and $H$. malabaricus revealed a difference between these host populations, caused by C. marginatum and Pseudoproleptus sp. (Fig. 3).

For $\mathrm{H}$. malabaricus, the abundance of $\mathrm{C}$. marginatum correlated positively with the length and negatively with the Kn of the hosts. In the same manner, the abundance of Contracaecum sp. correlated positively with host size and negatively with Kn. For $H$. unitaeniatus, there was a negative correlation between the abundance of $G$. spectabilis and host length, while the abundance of $C$. marginatum correlated positively with host length and body weight. The abundance of Contracaecum sp. also exhibited a positive correlation with host length (Table 4).

The condition factor of the parasitized $H$. malabaricus $(\mathrm{Kn}=0.999$ $\pm 0.063)$ did not differ $(t=-0.062 ; p=0.951)$ from the standard (Kn $=1.00$ ), and the same was true for $H$. unitaeniatus $(\mathrm{Kn}=1.00 \pm$ $0.017)(t=0.003, p=0.997)$. The equation describing the growth of

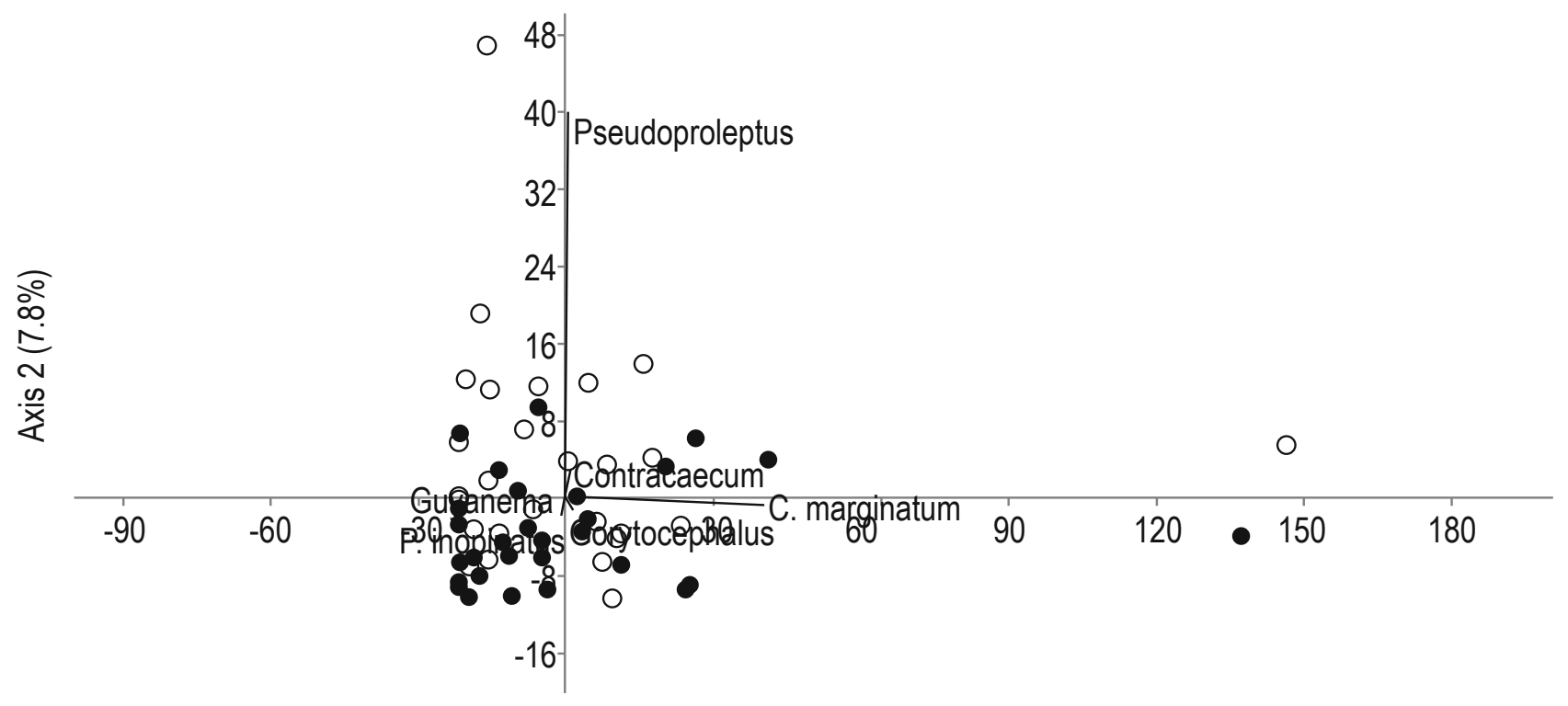

Axis $1(89.3 \%)$

Fig. 3. Scatterplot scores of the principal component analysis (PCA) on endoparasites of de Hoplias malabaricus (O) e Hoplerythrinus unitaeniatus (O) from Vila Nova River, eastern Amazon (Brazil). P. inopinatus: Procamallanus (Spirocamallanus) inopinatus, Guyanema: Guyanema serieri serieri, Gorytocephalus: Gorytocephalus spectabilis, Pseudoproleptus: Pseudoproleptus sp., C.marginatum: Clinostomum marginatum. 
Table 4. Spearman correlation coefficient ( $r s)$ of abundance of parasites with standard length, body weight and Kn for the infracommunities of parasite helminths of two species of Erythrinidae from the Vila Nova River basin, eastern Amazon region (Brazil).

\begin{tabular}{|c|c|c|c|c|c|c|c|c|c|c|c|c|}
\hline \multirow{3}{*}{$\begin{array}{l}\text { Hosts fish } \\
\text { Parasites }\end{array}$} & \multicolumn{6}{|c|}{ Hoplias malabaricus } & \multicolumn{6}{|c|}{ Hoplerythrinus unitaeniatus } \\
\hline & \multicolumn{2}{|c|}{ Length } & \multicolumn{2}{|c|}{ Weight } & \multicolumn{2}{|c|}{$\mathrm{Kn}$} & \multicolumn{2}{|c|}{ Length } & \multicolumn{2}{|c|}{ Weight } & \multicolumn{2}{|c|}{$\mathrm{Kn}$} \\
\hline & rs & $p$ & rs & $\mathrm{p}$ & rs & $\mathrm{p}$ & rs & $\mathrm{p}$ & rs & $\mathrm{p}$ & rs & $\mathrm{p}$ \\
\hline Pseudoproleptus sp. & 0.284 & 0.127 & 0.293 & 0.115 & -0.239 & 0.202 & 0.253 & 0.177 & 0.117 & 0.537 & -0.130 & 0.493 \\
\hline Gorytocephalus spectabilis & -0.159 & 0.400 & -0.252 & 0.177 & 0.035 & 0.851 & -0.432 & 0.017 & -0.304 & 0.101 & 0.041 & 0.826 \\
\hline Clinostomum marginatum & 0.467 & 0.001 & 0.361 & 0.049 & -0.593 & 0.0005 & 0.454 & 0.011 & 0.5671 & 0.001 & -0.186 & 0.322 \\
\hline Contracaecum sp. & 0.545 & 0.001 & 0.539 & 0.002 & -0.5137 & 0.0037 & 0.347 & 0.059 & 0.2314 & 0.218 & 0.033 & 0.859 \\
\hline Procamallanus (S.) inopinatus & - & - & - & - & - & - & -0.073 & 0.700 & -0.0008 & 0.996 & 0.213 & 0.257 \\
\hline Guyanema s. seriei & - & - & - & - & - & - & -0.253 & 0.176 & -0.246 & 0.188 & -0.032 & 0.865 \\
\hline
\end{tabular}

H. malabaricus was $\mathrm{W}=0.0891 \mathrm{~L}^{2.5057} ; \mathrm{r}^{2}=0.898$, while for $H$. unitaeniatus it was $\mathrm{W}=0.0327 \mathrm{~L}^{2.8978} ; \mathrm{r}^{2}=0.904$, which shows negative allometric type growth.

\section{Discussion}

The endoparasite fauna in $H$. malabaricus was composed by 1 species of Digenea, 4 Nematoda and 1 Acanthocephala, while in $H$. unitaeniatus it consisted of 1 species of Digenea, 2 Nematoda and 1 Acanthocephala. Thus, $66.6 \%$ of these taxa are known species for these hosts in the eastern Amazon region. The endoparasite communities of $H$. unitaeniatus and $H$. malabaricus were dissimi$\operatorname{lar}(15 \%)$ and were mostly influenced by the amount of ingested prey. However, a certain degree of homogeneity can be expected in hosts living in the same environment that are phylogenetically related and have a similar ecology (Alarcos \& Timi, 2012; Hoshino et al., 2016). The parasites of $H$. unitaeniatus and $H$. malabaricus presented aggregate dispersion, but $H$. unitaeniatus demonstrated greater species richness, a higher Brillouin index and lower Berger-Parker dominance. The greater species richness of endoparasites of $H$. unitaeniatus is an indication that their feeding is more diversified than $H$. malabaricus in the studied environment. This higher species richness of endoparasites in $H$. unitaeniatus can therefore result in a greater number of infected organs, thus causing a reduction in competition among endoparasites.

The parasite dispersion pattern in both $H$. malabaricus and $H$. unitaeniatus was aggregated, a pattern registered for others freshwater fish in Brazil (Luque et al., 2003, Guidelli et al., 2003; Tavares-Dias et al., 2014a,b; Oliveira et al., 2016, 2017). This pattern is mainly influenced by the breadth of the ecological niche dimension, environmental heterogeneity and host immunology (Anderson \& Gordon, 1982; Guidelli et al., 2003; Tavares-Dias et al., 2013; Oliveira et al., 2016). However, the infection by P. (S.) inopinatus in the pyloric cecum of $H$. unitaeniatus had a random dispersion, similar to the infection of this nematode in the pyloric cecum of $T$. angulatus from the Amazon River system (Oliveira et al., 2016). The random dispersion pattern is common in larvae and species of parasites with a high degree of pathogenicity, and that have a reduced possibility of colonizing hosts (Guidelli et al., 2003). Therefore, such parasite dispersion patterns may vary depending on the colonization strategies of the parasite species.

The growth type of $H$. malabaricus and $H$. unitaeniatus was negative allometric, indicating a greater increase in length than in body mass. In both $H$. malabaricus and $H$. unitaeniatus, there was a positive correlation between the abundance of $C$. marginatum and Contracaecum sp. and the size of the hosts. This is a strong indicator of the accumulation of these endoparasites throughout the life of these hosts, influenced mainly by the greater possibility of intermediate host ingestion, and a longer time of exposure to parasitic infections (Guidelli et al., 2003; Bicudo et al., 2005; Bellay et al., 2012). However, $H$. malabaricus and $H$. unitaeniatus, which are fish of sedentary habits (Santos et al., 2006, Soares et al., 2011), exhibited differences in the number of prey containing infective forms of the endoparasites found, thus demonstrating a relative overlap in the same environment investigated. The negative correlation between the abundance of $C$. marginatum and Contracaecum sp. and the size of $H$. malabaricus and the condition factor, indicates that larger fish have lower body conditions despite feeding more, and thus support lower levels of endoparasitic infection (Oliveira et al., 2016). However, a high abundance of parasites can compromise the body conditions of natural populations (Lizama et al., 2007; Morozińska-Gogol, 2015).

The digenean C. marginatum, a parasite with low parasitic specificity (Gonçalves et al., 2016) which occurred at similar levels of infection in $H$. malabaricus and $H$. unitaeniatus in the present study, was the dominant helminth in the community. The transmission of digenean species is directly related to the food habits of the host, since these endoparasites need more than one host to complete their biological cycle (Pinto et al., 2015; Oliveira et al., 2016, 2017). In Brazil, in general, metacercaria of Clinostomum spp. use Biomphalaria spp. mollusks as primary intermediate hosts (Dias et al., 2003; Pinto et al., 2015), and the H. malabaricus and H. unitaeniatus of the present study are the secondary intermediate hosts of this endoparasite, with piscivorous birds the definitive hosts (Dias et al., 2003; Pinto et al., 2015). 
The acanthocephalan G. spectabilis was found in the intestine, liver, pyloric cecum and mesentery of $H$. unitaeniatus, as well as in the mesentery of $H$. malabaricus, with varying rates of prevalence. However, its greatest abundance occurred in $\mathrm{H}$. unitaeniatus, which showed levels of infection similar to those described for this same host from another basin of the Amazon River system (Alcântara \& Tavares-Dias, 2015; Gonçalves et al., 2016). The life cycle of acanthocephalans involves vertebrate species as definitive hosts and microcrustaceans (amphipods, copepods, isopods and ostracods) as intermediate hosts (Huys \& Bodin, 1997). Fish become infected when they prey on microcrustaceans containing acanthella, which can reach the cystacanth and adult stages in $H$. malabaricus and $H$. unitaeniatus in the environment of this study, corroborating the results of Alcântara \& Tavares-Dias (2015), for these same host species.

Low levels of infection by G. s. seriei were found in $H$. unitaeniatus, indicating that this fish acts as definitive host for this nematode. This species of endoparasite was originally described from $\mathrm{H}$. unitaeniatus from French Guiana (Petter, 1975), indicating that these nematodes have a restricted relationship with $H$. unitaeniatus, while $H$. malabaricus is parasitized by Guyanema baudi (Weiblen \& Brandão, 1992). However, G. s. seriei and G. baudi use different species of fish as primary and secondary intermediate hosts. This study extends the distribution of G. s. seriei to the basin of the Vila Nova River. A high prevalence but low abundance of larvae of Contracaecum sp. was found in $H$. unitaeniatus and $H$. malabaricus, although the latter host was less parasitized. However, there was a higher level of Contracaecum sp. infection of $H$. malabaricus than $H$. unitaeniatus in another basin in the Amazon River system, due to a larger range of items present in the diet of $H$. malabaricus in the studied environment (Alcântara \& Tavares-Dias, 2015; Gonçalves et al., 2016). In general, nematodes use microcrustacean species as primary intermediate hosts, while fish may be paratenic, secondary or definitive intermediate hosts (Moravec, 2009; Moreira et al., 2009). Contracaecum species use piscivorous birds as definitive hosts (Moravec, 2009; Tavares-Dias et al., 2014a).

Procamallanus (S.) inopinatus, a nematode with no parasitic specificity and with wide distribution in Brazil, uses fish species as definitive hosts and species of chironomids as intermediate hosts (Moravec, 1998; Moreira et al., 2009; Tavares-Dias et al., 2014b; Oliveira et al., 2015; Oliveira et al., 2016). This nematode was found only in $H$. unitaeniatus and with lower infection levels than those reported for this same host from the Igarapé Fortaleza basin, a tributary of the Amazon River (Alcântara \& Tavares-Dias, 2015; Gonçalves et al., 2016), a finding probably influenced by the lower availability of intermediate hosts in the environment. However, $H$. unitaeniatus and $H$. malabaricus are the definitive hosts for this endoparasite (Alcântara \& Tavares-Dias, 2015). This study extends the distribution of $P$. (S.) inopinatus to the basin studied.

A high prevalence of Pseudoproleptus sp. occurred in $H$. unitaeniatus and $H$. malabaricus, but the highest levels of infection were found in $H$. malabaricus. In the Eastern Amazon region, the larvae of Pseudoproleptus sp. were also reported in Satanoperca jurupari (Melo et al., 2011) and Aequidens tetramerus (Tavares-Dias et al., 2014a), as cichlid species are possibly part of the diet of $H$. malabaricus and $H$. unitaeniatus, which makes the transmission and development of this nematode even more efficient. Pseudoproleptus sp. uses larvae of ephemeral insects and crustaceans as the first intermediate hosts (Moravec, 2007; Moravec \& Santos, 2009) while some species of fish act as second intermediate hosts (Moravec and Santos, 2009, Melo et al., 2011, Tavares-Dias et al., 2014a) and even as a definitive host, such as H. malabaricus (Melo et al., 2011). This is the first record of Pseudoproleptus sp. for $H$. unitaeniatus and extends its geographic distribution to the basin of the Vila Nova River.

In summary, the endoparasites community of $H$. malabaricus and $H$. unitaeniatus was characterized by the predominance of larvae, indicating that these fish are intermediate hosts for most of the parasite species found here. Therefore, these two hosts occupy a central position in the food chain. Finally, the high similarity between the community of endoparasites of $H$. malabaricus and $H$. unitaeniatus indicate a high overlap in environment. There also does not appear to be interspecific competition between the parasites, as they occupy several sites in the host.

\section{Conflict of Interest}

Authors state no conflict of interest.

\section{Acknowledgements}

The authors would like to thank the Coordenação de Aperfeiçoamento de Pessoal de Nível Superior (Coordination for the Improvement of Higher Level Education Personnel) (Capes) for the doctorate grant awarded to Oliveira, M.B.O and Neves, L.R. and master's grant awarded to Brasiliense, A.R.P. and to the Conselho Nacional de Desenvolvimento Científico (the National Scientific Development Council) (CNPq) for the productivity grant awarded to Tavares-Dias, M., and to Mr. José C.C. Pinto for the availability of the area for collection and help in fishing.

\section{References}

Alarcos, A.J., TImı, J.T. (2012): Parasite communities in three sympatric flounder species (Pleuronectiformes: Paralichthyidae): similar ecological filters driving toward repeatable assemblages. Parasitol. Res., 110(6): 2155 - 2166. DOI: 10.1007/s00436-011-2741-5 ALCÂNTARA, N.M., TAVARES-DIAS, M. (2015): Structure of the parasites communities in two Erythrinidae fish from Amazon River system (Brazil). Braz. J. Vet. Parasitol., 24(2): 183 - 190. DOI: 10.1590/ S1984-29612015039

Anderson, R.M., GoRdon, D.M. (1982): Processes influencing the distribution of parasite numbers within host populations with special emphasis on parasite-induced host mortalities. Parasitology, 85(2): 
373 - 98. DOI: 10.1017/S0031182000055347

Bellay, S., Ueda, B.H., Takemoto, R.M., Lizama, M.A.P., Pavanell, G.C. (2012): Fauna parasitária de Geophagus brasiliensis (Perciformes: Cichlidae) em reservatórios do Estado do Paraná, Brasil [Parasitic fauna of Geophagus brasiliensis (Perciformes: Cichlidae) in the State of Paraná, Brazil]. Rev. bras. Bioci., 10(1): 74 - 78 (In Portuguese)

Bicudo, A.J.A., TAVARES, L.E.R., LUQue, J.L. (2005): Metazoários parasitos da cabrinha Prionotus punctatus (Bloch, 1793) (Osteichthyes: Triglidae) do litoral do Estado do Rio de Janeiro, Brasil [Metazoan parasites of the goat cabbage Prionotus punctatus (Bloch, 1793) (Osteichthyes: Trigilidae) of the coast of the State of Rio de Janeiro, Brazil]. Rev. bras. Parasitol. Vet., 14(1): 27 - 33 (In Portuguese)

Bush, A.O., LafFerty, K.D., Lotz, J.M., Shostak, W. (1997): Parasitology meets ecology on its own terms: Margolis et al. Revisited. J. Parasitol., 83(4): 575 - 583. DOI: 10.2307/3284227

Caffara, M., Locke, S.A., Gustinelli, A., Marcoglese, D.J., FioraVANTI, M.L. (2011): Morphological and molecular differentiation of Clinostomum complanatum and Clinostomum marginatum (Digenea: Clinostomidae) metacercariae and adults. J. Parasitol., 97(5): 884 - 891. DOI: 10.1645/GE-2781.1

Corréa, L.L., Karling, L.C., Takemoto, R.M., Ceccarell, P.S., Ueta, M.T. (2013): Hematological alterations caused by high intensity of L3 larvae of Contracaecum sp. Railliet \& Henry, 1912 (Nematoda, Anisakidae) in the stomach of Hoplias malabaricus in lakes in Pirassununga, São Paulo. Parasitol. Res., 112(8): 2783 - 2789. DOI: 10.1007/s00436-013-3446-8

Corrêa, L.L., Souza, G.T., Takemoto, R.M., Ceccarell, P.S., AdrlANo, E.A. (2014): Behavioral changes caused by Austrodiplostomum spp. in Hoplias malabaricus from the São Francisco River, Brazil. Parasitol. Res., 113(2): 499 - 503. DOI: 10.1007/s00436013-3679-6

CunHA, A.C. (2003): Levantamento de parâmetros físico-químicos e hidráulicos para a avaliação da qualidade da água em escoamento natural na bacia hidrográfica do Rio Vila Nova - O desenvolvimento do distrito industrial de Santana-AP [Survey of physico-chemical and hydraulic parameters for the evaluation of the quality of the water in natural drainage in the river basin of the Vila Nova River - The development of the industrial district of Santana -AP]. Macapá-AP, CPAQ, IEAP, 74 pp. (In Portuguese)

Dias, M.L.G.G., Eiras, J.C., Machado, M.H., Souza, G.T.R., PAVANELLI, G.C. (2003): The life cycle of Clinostomum complanatum Rudolphi, 1814 (Digenea, Clinostomidae) on the floodplain of the high Paraná River, Brazil. Parasitol. Res., 89(6): 506 - 508. DOI 10.1007/s00436-002-0796-z

EIRAS, J.C., TAKemoto, R.M., Pavanelli, G.C. (2006): Métodos de estudo e técnicas laboratoriais em parasitologia de peixes [Study and laboratory techniques in fish parasitology]. $2^{\text {nd }}$ Edition, Maringá, Eduem, 199 pp. (In Portuguese)

Gonçalves, R.A., Oliveira, M.S.B., Neves, L.R., Tavares-Dias, M. (2016): Seasonal pattern in parasite infracommunities of Hoplerythrinus unitaeniatus and Hoplias malabaricus (Actinopterygii: Erythri- nidae) from the Brazilian Amazon. Acta Parasitol., 61(1): 119 - 129. DOI: 10.1515/ap-2016-0016

Guidell, G.M., Isaac, A., Takemoto, R.M., Pavanelli, G.C. (2003): Endoparasite infracommunities of Hemisorubim platyrhynchos (Valenciennes, 1840) (Pisces: Pimelodidae) of the Baía River, upper Paraná River floodplain, Brazil: specific composition and ecological aspects. Braz. J. Biol., 63(2): 261 - 268. DOI: 10.1590/S151969842003000200011

Hammer O., Harper, D.A.T., Ryan, P.D. (2001): PAST: paleontological statistics software package for education and data analysis. Palaeontol. Electron., 4: 1 - 9.

Hoshino, M.D.F.G., Neves, L.R., Tavares-Dias, M. (2016): Parasite communities of the predatory fish, Acestrorhynchus falcatus and Acestrorhynchus falcirostris, living in sympatry in Brazilian Amazon. Braz. J. Vet. Parasitol., 25(2): 207 - 216. DOI: 10.1590/S198429612016038

HuYs, R., Bodin, P. (1997): First record of Acanthocephala in marine copepods. Ophelia, 46(3): 271 - 231. DOI: 10.1080/00785326.1997.10432880

LE-CREN, E.D. (1951): The lenght-weight relationship and seasonal cycle in gonad weight and condition in the perch (Perca fluviatilis). J. Anim. Ecol., 20(2): 201 - 219. DOI: 10.2307/1540

Lizama, M.A.P., Takemoto, R.M., Ranzanl-Paiva, M.J.T., Ayroza, L.M.S., PavanelLI, G.C. (2007): Relação parasito-hospedeiro em peixes de pisciculturas da região de Assis, Estado de São Paulo, Brasil. 1. Oreochromis niloticus (Linnaeus, 1757) [Host-parasite relationship in fish from fish farms in the Assis region, São Paulo State, Brazil. 1. Oreochromis niloticus (Linnaeus, 1757)]. Acta Sci. Biol. Sci., 29(2): 223 - 231. DOI: 10.4025/actascibiolsci.v29i2.594 (In Portuguese)

LUDWIG, J.A., REYNoLds, J.F. (1988): Statistical ecology: a primer on methods and computing. New York, Wiley-Interscience Pub, 337 pp. LUQUe, J.L., Alves, D.R., RIBEIRO, R.D.S. (2003): Community ecology of the metazoan parasites of Banded Croaker, Paralonchurus brasiliensis (Osteichthyes: Sciaenidae), from the coastal zone of the State of Rio de Janeiro, Brazil. Acta Sci. Biol. Sci., 25(2): 273 - 278 Machado, M.H., Souza, G.T.R., RibeIRo, T.S. (2013): Regulação parasitária em ecossistemas dulcícolas [Parasitic regulation in sweet ecosystems]. In: Pavanell, G.C., TaKemoto, R.M., ElRAS, J.C. (Eds) Parasitologia em peixes de água doce do Brasil [Parasitology in Freshwater Fishes of Brazil]. Maringá, PR, Eduem, pp. 17 - 35 (In Portuguese)

MagurRan, A.E. (2004): Measuring biological diversity. Oxford, Blackwell Science, $264 \mathrm{pp}$.

Mattox, G.M.T., Toledo-Piza, M., Oyakawa, O.T. (2006): Taxonomic study of Hoplias aimara (Valenciennes, 1846) and Hoplias macrophthalmus (Pellegrin, 1907) (Ostariophysi, Characiformes, Erythrinidae). Copeia, 2006(3): 516 - 528. DOI: 10.1643/ 0045-8511(2006)2006[516:TSOHAV]2.0.CO;2

Melo, M.F.C., Giese, E.G., Santos, J.N., Portes Santos, C. (2011): First record of larval Pseudoproleptus sp. (Nematoda: Cystidicolidae) in fish host. Acta Tropica, 117(3): 212 - 215. DOI: 10.1016/j. 
actatropica.2010.12.011

MoRAVEc, F. (1998): Nematodes of freshwater fishes of the Neotropical region. Praha, Vydala Academia, 464 pp.

Moravec, F. (2007): Some aspects of the taxonomy and biology of adult spirurine nematodes parasitic in fishes: a review. Folia Parasitol., 54(4): 239 - 257. DOI: 10.14411/fp.2007.033

Moravec, F. (2009): Experimental studies on the development of Contracaecum rudolphii (Nematoda: Anisakidae) in copepod and fish paratenic hosts. Folia Parasitol., 56(3): 185 - 193. DOI: 10.14411/fp.2009.023

Moravec, F., Santos, P. (2009): Larval Pseudoproleptus sp. (Nematoda: Cystidicolidae) found in the Amazon River Prawn Macrobrachium amazonicum (Decapoda: Palaemonidae) in Brazil. J. Parasitol., 95(3): 634 - 638. DOI: 10.1645/GE-1887.1

Moreira, L.H.A., Takemoto, R.M., Yamada, F.H., CeschinI, T.L., PAVANELLI, G.C. (2009): Ecological aspects of metazoan endoparasites of Metynnis lippincottianus (Cope, 1870) (Characidae) from upper Paraná River floodplain, Brazil. Helminthologia, 46(4): 214 - 219. DOI: 10.2478/s11687-009-0040-9

MoRozińSKA-GogoL, J. (2015): Changes in the parasite communities as one of the potential causes of decline in abundance of the three-spined sticklebacks in the Puck Bay. Oceanologia, 57(3): 280 - 287. DOI: 10.1016/j.oceano.2015.03.001

Oliveira, M.S.B., Gonçalves, R.A., Ferreira, D.O., Pinheiro, D.A., NeVES, L.R., Dias, M.K.R., TAVARES-Dias, M. (2017): Metazoan parasite communities of wild Leporinus friderici (Characiformes: Anostomidae) from Amazon River system in Brazil, Stud. Neotrop. Fauna Environ., 52(2): 146 - 156. DOI: 10.1080/01650521.2017.1312776 Oliveira, M.S.B., Gonçalves, R.A., Neves, L.R., Tavares-Dias, M. (2015): Endohelmintos parasitos de Metynnis hypsauchen (Characidae) da bacia do Rio Jari, Amazônia brasileira [Endohelminth parasites of Metynnis hypsauchen (Characidae) from the Jari River basin, Brazilian Amazonia]. Neotrop. Helminthol., 9(2): 235 - 242 (In Portuguese)

Oliveira, M.S.B., Gonçalves, R.A., Tavares-Dias, M. (2016): Community of parasites in Triportheus curtus and Triportheus angulatus (Characidae) from a tributary of the Amazon River system (Brazil). Stud. Neotrop. Fauna Environ., 51(1): 29 - 36. DOI: 10.1080/01650521.2016.1150095

Petter, A.J., (1974): Deux nouvelles espèces de Nematodes Camallanina parasites de Hoplerythrinus unitaeniatus (Characidac, Cypriniformes) en Guyane; création d'une nouvelle famille: les Guyanemidae (Dracunculoidea) [Two new species of Nematodes Camallanina parasites of Hoplerythrinus unitaeniatus (Characidac, Cypriniformes) in French Guiana; creation of a new family: Guyanemidae (Dracunculoidea)]. Zoologie, 156(3): 803 - 812 (In Portuguese)

Pinto, H.A., Caffara, M., Fioravanti, M.L., Melo, A.L. (2015): Experimental and molecular study of cercariae of Clinostomum sp. (Trematoda: Clinostomidae) from Biomphalaria spp. (Mollusca: Planorbidae) in Brazil. J. Parasitol. 101(1): 108 - 113. DOI: 10.1645/14-497.1 Rohde, K., Hayward, C., Heap, M. (1995): Aspects of the ecology of metazoan ectoparasites of marine fishes. Int. J. Parasitol., 25:(8): 945 - 970. DOI: 10.1016/0020-7519(95)00015-T

Rózsa, L., Reiczigel, J., Majoros, G. (2000): Quantifying parasites in samples of hosts. J. Parasitol., 86(2): 228 - 232. DOI: 10.1645/0022-3395(2000)086[0228:QPISOH]2.0.CO;2

Santos, G.M., Ferreira, E.J.G., Zuanon, J.A.S. (2006): Peixes comerciais de Manaus [Commercial fish from Manaus]. Manaus, AM, Ibama/AM, PróVárzea, 144 pp. (In Portuguese)

SILVA, S.L.F., TAKIYAmA, L.R., Silva, U.R.L. (2006): Atlas da Zona Costeira Estuarina do Estado do Amapá: do diagnóstico socioambiental ao Zoneamento Ecológico-Econômico Costeiro Participativo [Atlas of the Zone Coastal State of Amapá: from the socio-environmental diagnosis to the Ecological-Economic Zoning Participatory]. Macapá, AP: IEPA, 77 pp. (In Portuguese)

Siqueira-Souza, F.K., Bayer, C., Caldas, W.H., Cardoso, D.C., Yamamoto, K.C., FreitAS, C.E.C. (2017): Ecomorphological correlates of twenty dominant fish species of Amazonian floodplain lakes. Braz. J. Biol., 77(1): 199 - 206. DOI: 10.1590/1519-6984.16215 Soares, M.G.M., Costa, E.L., SiquelRa-SouzA, F., Anjos, H.D.B., Yamamoto, K.C., Freitas, C.E.C. (2011): Peixes de Lagos do Médio Rio Solimões [Fish from Lagos of the Middle Solimões River]. $2^{\text {nd }}$ Edition, Manaus, AM, Instituto Piatam, 176 pp. (In Portuguese)

Tavares-Dias M., Neves, L.R., Pinheiro, D.A., Oliveira, M.S.B., MarINHO, R.G.B. (2013): Parasites in Curimata cyprinoides (Characiformes: Curimatidae) from eastern Amazon, Brazil. Acta Sci. Biol. Sci., 35(4): 595 - 601. DOI: 10.4025/actascibiolsci.v35i4.19649

Tavares-Dias M., Oliveira, M.S.B., Gonçalves, R.A., Silva, L.M. (2014a): Ecology and seasonal variation of parasites in wild Aequidens tetramerus, a Cichlidae from the Amazon. Acta Parasitol., 59(1): 158 - 164. DOI: 10.2478/s11686-014-0225-3

Tavares-Dias, M., SouzA, T.J.S., Neves, L.R. (2014b): Parasitic infections in two benthopelagic fish from amazon, the arowana Osteoglossum bicirrhosum (Osteoglossidae) and oscar Astronotus ocellatus (Cichlidae). Biosci. J., 30(2): 546 - 555.

Thatcher, V. E. (2006): Amazon fish parasites. $2^{\text {nd }}$ Edition, Moscow, Pensoft Publishers, Sofia, 508 pp.

Vicente, J.J., Pinto, R.M. (1999): Nematoides do Brasil. Nematoides de peixes. Atualização: 1985 - 1998 [Nematoides of Brazil. Nematoides of fish. Update: 1985 - 1998]. Rev. bras. Zool. 16(3): 561 - 610 (In Portuguese)

Welblen, A.M., BRAndão, D.A. (1992): Levantamento parasitológico em Hoplias malabaricus, Bloch, (1794) (Traíra) de águas da região de Santa Maria - RS [Survey of parasites of Hoplias malabaricus, Bloch, (1794) in Santa Maria county]. Cienc. Rural, 22(2): 203 208. DOI: 10.1590/S0103-84781992000200014 (In Portugues)

ZAR, J.H. (2010): Biostatistical analysis. $5^{\text {nd }}$ Edition, New Jersey, Prentice Hall, $960 \mathrm{pp}$.

Zee - Zoneamento Ecológico Econômico (1997): Primeira aproximação do zoneamento ecológico econômico do Amapá. Representação escala 1/1.000.000 [First approximation of the ecological ecological zoning of Amapá. Scale representation 1/1.000.000]. Macapá, AP, IEPA-ZEE, 106 pp. (In Portuguese) 